\title{
THE ROLES OF GOVERNMENT DEPARTMENTS
}

\author{
A. McG. Peart*
}

The direct responsibility for local action in the event of natural disasters in New Zealand falls on the urban and rural local authorities affected, but the structure of New Zealand's society in general assigns departments of central Government key roles. This applied particularly to the West Coast following the earthquake. The Coast has long been struggling as an economic region and has to a degree become dependant on a number of central Government activities for its economic existence. Government departments therefore played a significant and perhaps critical part in actions which followed the Inangahua disaster. Those with establishments in the affected area of Hokitika, Greymouth, Reefton, Inangahua, and Westport were Social Security and State Advances (normally concerned with social and financial affairs), the Ministry of Works, N.Z. Electricity Department, N.Z. Post Office, N.Z。 Railways, and Police (responsible for physical works or the provision of essential community services)。 Departments in the second group are experienced in dealing with the effects of frequent emergencies as far as their equipment and services are concerned, and were thus able and ready to deal effectively with many problems created by the earthquake.

Access to the West Coast, and in particular to the most damaged areas, is by railway and state highway both of which are under the direct control of Government departments. Similarly, telegraphic and telephonic communication is a departmental responsibility, as is also transmission of electric power to the region. Repairs to these services are all essential to the speedy relief and recovery of a devastated area, so that the contribution of the departments concerned was critical to the success of general rescue, welfare, and restoration.

The three broad phases which generally follow an earthquake did seem to occur on the West Coast. These were firstly the shock phase during which the magnitude of damage and its effects was difficult to ascertain speedily, rescue work was spontaneous and unco-ordinated, and people were unsure of what had happened. This period is estimated to have lasted some hours in and around Inangahua. Then followed the rescue and welfare phase known as "civil defence", during which organised activity was concentrated on rescue work and care of the injured and displaced. Considerable powers were available to (but only in some cases assumed by) local authority civil defence organisations on the vest Coast. This phase continued for a period of approximately six days.

Lastly the restoration phase overlapped the civil defence phase almost completely through the activities of Government departments which pursued their own specialised restoration work immediately following the earthquake, besides assisting local authorities in their civil defence problems wherever advice or other services were requested.

Departmental assistance to local authorities in the main took the form of advice in technical, administrative and financial fields, but some urgently needed building materials which were also despatched to needy areas. Manpower, and earthmoving machinery was available but not required for rescue work. 
Some departments, notably the Ministry of Works and NoZ。 Electricity Department, had excellent communication systems, the former a wide radio coverage of the area with a station at Inangahua, and the latter a private telephone network including Inangahua. It is believed that the first report from Inangahua came through the $N_{\circ} Z_{\circ} E_{\circ} D_{\circ}$ system。 These proved invaluable during the emergency, and in fact in the early stages were the only means of gaining an assessment of the situation. The Ministry of Works in particular was well placed to assist because of an already established central operations room in its Head Office from which communication could be maintained, not only with its radio stations all over New Zealand, but also directly, if necessary, with stations and mobile sets in the disaster area. Besides proceeding with its normal tasks, a Ministry of Works contribution was made by, firstly assessing the broad situation from local radio chatter, (the weather was poor and many roads on the Coast were blocked by debris so that direct reconnaissance was not possible until later by air), feeding information to the national civil defence headquarters in Wellington, and secondly by assessing the technical implications of reports from the disaster scene. It is of interest to note that a technical assessment of risks associated with a reported massive blockage of the Buller river above Inangahua was one of the factors involved in the decision to evacuate Inangahua urgently。

As the situation progressed press, radio, and television teams entered the disaster area and general situation reports from this source became more up-to-date than those received through departmental channels, although it was observed that emphasis was placed rather on emotional aspects. The national civil defence headquarters was by this time receiving excellent situation reports from its own organisation and departmental reports were useful only in filling in knowledge gaps. At this stage situation reports from departments tended to become a technical yardstick for measurement of the accuracy of press and radio reports from the local scene.

Engineers, scientists, and damage assessors, from Government departments were swiftly on the scene and were of assistance in providing technical and scientific appraisals of various facets of the disaster. Information flowed into the Head Offices of the various departments involved and was co-ordinated as necessary by cross consultation in Wellington.

For a time much of the departmental information was fed to the national civil defence headquarters in Wellington, but the tendency after the shock phase, which lasted only for some hours, was for civil defence to proceed with its task of rescue, welfare, and elimination of hazards while departmental thoughts turmed more towards planning for restoration.

The first steps to commence rehabilitation took the form of consultation between the Ministry of Works, N.Z. Railways, N.Z. Post Office, N.Z. Electricity Department, the Social Security Commission, and the Earthquake and War Damage Commission. The situation pertaining to each department was discussed and an initial assessment made of the needs of each to accelerate restoration of the services for which it was responsible。 Almost immediately afterwards, a much more widely representative meeting of departments was convened with the objective of considering what was involved in general restoration and rehabilitation and how best this might be achieved expeditiously. Two major aspects, those of welfare (including relief payments to displaced families), and physical restoration were involved. In the case of welfare and national civil defence plan for welfare (already prepared) proved of great assistance, and the main task in this field became that of detailing 
specific levels of assistance. The problem of physical restoration was more complex however, and even at the present time has not been fully solved. It is worthy of note that many of the problems highlighted by the earthquake are now being studied with a view to their avoidance in the future.

The course adopted depended for its success upon full and active participation by the territorial local authorities in the restoration programme with control being exercised through the normal powers and functions available under various enactments。 To assist the local government organisation restoration co-ordination committees were established in the towns of Westport, Reefton, and Greymouth with the task of assessing the nature and extent of any assistance required from outside the damaged area, of recommending appropriate action to obtain this assistance, and of generally acting as receiving centres for unresolved problems encountered in damaged areas. Each committee had 5 members, 3 representing Government departments, and 2 representing urban and rural local authorities. The Reefton committee had the additional task of assuming responsibility for the restoration of Inangahua itself.

The three committees were responsible to the District Commissioner of Works, Christchurch, (in whose district the diaster area lay) and he in turn referred problems to Wellington.

The achievements of this approach to restoration proved variable for a number of reasons, but in general restoration targets were not achieved at the intended pace, and some perplexing problems still remain, not the least being that of finance in the private sector. The existence of the committees however proved very helpful in exposing shortcomings in existing procedures, and much insight was gained into the needs of restoration organisations which might deal with future earthquake problems.

In the private sector of the community in particular, it seems that speedy and effective restoration depends greatly on the extent to which property-owners have insured against diaster. In a devastating earthquake, restoration problems will be largely financial in character, and failure by individuals to participate adequately in available schemes for protection against such contingencies can only complicate the restoration process; or even make its full achievement impossible。

One major conclusion from the Inangahua earthquake has been that rehabilitation and restoration is a process of participation by the whole community, greatly assisted by reasonable provision in advance by propertyowners. The role of Government departments has its limits, however wellintentioned the departments themselves might be. It is indeed fortunate that the Inangahua earthquake did not have its epicentre in a densely populated area.: 